\title{
Pendugaan Umur Simpan Cabai Merah Kering (Capsicum annuum L.) dengan Metode Konvensional
}

\section{Estimation of Shelf Life Dried Chillies (Capsicum annuum L.) Using Conventional Methods}

\author{
Hisworo Ramdani ${ }^{1,2^{*}}$ dan Siti Fatimah ${ }^{3}$ \\ 'Program Studi Ilmu dan Teknologi Pangan, Fakultas Bioindustri, Universitas Trilogi, Jakarta, Indonesia \\ ${ }^{2}$ Pusat Kajian Hortikultura Tropika (PKHT) Institut Pertanian Bogor, Kampus IPB Baranangsiang \\ Jl. Raya Pajajaran Bogor, Indonesia \\ ${ }^{3}$ Program Studi dan Teknologi Industri Pertanian, Fakultas Ilmu Pangan Halal, Universitas Djuanda Bogor, Indonesia
}

Diterima 28 Januari 2019/Disetujui 22 Februari 2019

\begin{abstract}
Food processing in the industry aims to extend the shelf life of a product. Shelf life is one of the requirements that must be evaluated before food products were marketed and safety for consumption. Estimation of shelf life was done by conventional methods. The conventional methode that was storage of some products at room temperature conditions which have the same weight and date of production. Observations data were taken on parameters of water content, vitamin $C$, color and total microbes (TPC). The experimental design taken partially staggered design by simple regression. The results showed that

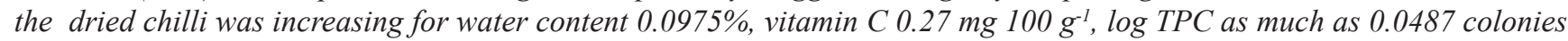
$g^{-1}$ and chili color which remained stable in the range of 16-18.3 chroma of storage for 24 days. Based on the results of the calculation of the conventional method, the linear regression equation of water content was $y=0.0975 x+8.0732$ so that it obtained 71 days shelf life and based on log TPC regression was $y=0.0487 x+8.1831$ obtained 65 days shelf life.
\end{abstract}

Keywords : dried chili, conventional method, regression, shelf life

\section{ABSTRAK}

Pengolahan pangan pada industri bertujuan untuk memperpanjang umur simpan suatu produk. Umur simpan merupakan salah satu persyaratan yang harus dipenuhi sebelum produk pangan dipasarkan, sehingga aman dikonsumsi oleh masyarakat. Penentuan umur simpan dilakukan dengan metode konvensional, yaitu menyimpan serangkaian produk pada kondisi suhu kamar yang memiliki berat dan tanggal produksi yang sama. Pengamatan dilakukan terhadap parameter kadar air, vitamin C, warna dan total mikroba (TPC). Rancangan percobaan yang digunakan dalam penelitian ini adalah partially staggered design sehingga dalam penerapannya dapat dilakukan pengolahan data menggunakan regresi sederhana. Hasil penyimpanan selama 24 hari diperoleh peningkatan nilai kadar air sebanyak $0.0975 \%$, vitamin C $0.27 \mathrm{mg} 100 \mathrm{~g}^{-1}, \log$ TPC

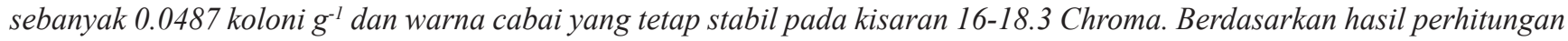
metode konvensional, persamaan regresi linier untuk kadar air adalah $y=0.0975 x+8.0732$, sehingga diperoleh umur simpan 71 hari dan berdasarkan regresi log TPC adalah $y=0.0487 x+8.1831$, sehingga diperoleh umur simpan 65 hari.

Kata kunci : cabai kering, metode konvensional, regresi, umur simpan

\section{PENDAHULUAN}

Cabai merah merupakan produk hortikultura yang mudah rusak namun disukai hampir oleh seluruh lapisan masyarakat. Cabai merah segar biasanya digunakan sebagai penyedap masakan yang memiliki rasa pedas atau sebagai garnish pada makanan. Mengingat sifat alamiyah sayuran yang mudah rusak, busuk dan tidak tahan lama, umumnya cabai merah segar dijadikan produk olahan, terlebih ketika panen cabai merah melimpah. Salah satu alternatif

\footnotetext{
* Penulis untuk korespondensi. e-mail: hisworor@gmail.com
}

pengolahan cabai segar menjadi produk yang lebih tahan lama, praktis dan bernilai ekonomi adalah cabai merah kering.

Cabai merah kering merupakan cabai segar yang dikeringkan dengan cara menurunkan kadar air yang dikandungnya. Proses pengeringan lazim digunakan untuk memperpanjang masa simpan produk dengan menggunakan alat pengering maupun bantuan sinar matahari. Deasy (2003) mengatakan bahwa produk diversifikasi hasil olahan yang dapat meningkatkan umur simpan seperti layaknya melalui pengeringan, dapat menjangkau pasaran yang lebih luas dan 
lebih terjamin ketersediaannya jika dibutuhkan dalam waktu singkat. Produk cabai kering mempunyai prospek pasar didalam dan luar negeri yang cukup baik. Produk pangan bersifat mudah rusak oleh berbagai faktor, baik kimiawi, fisik maupun mikrobiologis yang akan menurunkan mutu dari produk pangan tersebut. Produk pangan seperti cabai merah kering juga rentan terhadap kerusakan yang dapat menyebabkan penurunan mutu produk. Untuk itu diperlukan penelitian terhadap penentuan umur simpan produk cabai merah kering, sehingga dapat diketahui batas simpan produk yang masih layak disajikan ke konsumen.

Umur simpan merupakan suatu parameter ketahanan produk selama penyimpanan. Menurut Arpah (2001), pendugaan umur simpan dapat dilakukan dengan metode konvensional dan metode akselerasi. Metode konvensional membutuhkan waktu lama karena pendugaan umur simpan dilakukan dalam kondisi normal sehari-hari. Namun demikian, metode ini sangat akurat dan tepat. Metode akselerasi dapat dilakukan dalam waktu relatif singkat pada kondisi ekstrim namun tetap memiliki ketepatan dan akurasi yang tepat. Pada penelitian ini dilakukan penentuan masa umur simpan produk cabai merah kering yang diblansir dengan metode konvensional.

\section{BAHAN DAN METODE}

\section{Bahan dan Alat}

Bahan utama yang digunakan dalam penelitian ini adalah cabai merah keriting varietas TM 99, indikator amilum $1 \%$, larutan iod, aquades, plastik LDPE, NaCL $0.85 \%$ dan nutrient agar (NA). Alat yang digunakan dalam penelitian ini adalah pengering tunnel dehydrator, timbangan digital, stopwatch, alat steam, timbangan camry elektronik pocket scale model EHA 352, termometer, oven, cawan, buret, erlenmeyer, gelas ukur, pipet mohr dan gelas piala.

\section{Perlakuan Pendahuluan}

Perlakuan pendahuluan yaitu membuat produk cabai merah kering dan analisis karakterisasi produk. Proses pembuatan produk cabai merah kering diawali dengan penyortiran dan pencucian cabai segar. Setelah tahap tersebut selesai, cabai segar dianalisis kadar air, warna dan vitamin $\mathrm{C}$ yang dikandungnya. Cabai segar di blansir pada suhu $98^{\circ} \mathrm{C}$ selama 11 menit, kemudian cabai didinginkan. Tahap berikutnya yaitu pengeringan cabai merah menggunakan tunnel dehydrator pada suhu $70{ }^{\circ} \mathrm{C}$ selama 8 jam. Cabai kemudian dianalisis kadar air (AOAC, 1995), warna dan vitamin C (Sudarmadji, 1997).

\section{Penyimpanan Produk}

Produk cabai merah kering disimpan pada tempat penyimpanan dengan kondisi suhu ruang serta RH sekitar $75 \%$. Pengamatan dilakukan setiap tiga hari sekali untuk mengetahui perubahan yang terjadi selama penyimpanan, dengan uji vitamin $\mathrm{C}$, uji kadar air, warna dan uji TPC/total mikroba (SNI 01-2332.03-2006). Pengamatan dihentikan sampai perubahan yang terjadi menunjukkan penurunan mutu sehingga produk sudah tidak layak dikonsumsi.

\section{Rancangan Percobaan}

Rancangan percobaan yang diambil dalam penelitian ini adalah partially staggered design sehingga dalam penerapannya dapat dilakukan pengolahan data menggunakan regresi sederhana. Tujuan utama dari analisis regresi adalah untuk memberikan dasar-dasar peramalan atau pendugaan dalam analisis peragam atau analisis kovarian.

Analisis regresi dikenal dua macam variabel atau peubah yaitu variabel bebas $\mathrm{X}$ (independent variabel) dan variabel tidak bebas Y (dependent variabel). Variabel bebas adalah suata variabel yang nilainya telah diketahui, sedangkan variabel tidak bebas adalah variabel yang nilainya belum diketahui dan yang akan diramalkan (Dahlia, 2002). Secara sistematis rumus dari regresi linier sederhana dapat dituliskan dengan model persamaan sebagai berikut :

$$
\mathrm{Y}=\mathrm{A}+\mathrm{BX}
$$

Dimana $: \mathrm{Y}=$ variabel tak bebas, $\mathrm{X}=$ variabel bebas, $\mathrm{A}=$ intersep (jarak titik asal dengan titik potong garis pada sumbu $\mathrm{Y}$ ), $\mathrm{B}=$ slup (kemiringan atau kecondongan garis pada sumbu $\mathrm{X}$ )

\section{HASIL DAN PEMBAHASAN}

\section{Karakteristik Cabai Merah Keriting}

Cabai merah keriting yang digunakan pada penelitian ini adalah cabai varietas TM 999, yaitu cabai yang sangat umum di masyarakat dan mudah dijumpai. Cabai merah keriting di dapat dari pasar Bogor sebanyak $6 \mathrm{~kg}$ dengan rendemen $90 \%$ melalui proses penyortiran. Cabai merah keriting yang digunakan berdiameter 1.0-1.2 cm dengan panjang $\pm 10-12 \mathrm{~cm}$. Laju penurunan mutu cabai kering diperoleh berdasarkan perbandingan karakteristik mutu cabai segar dengan cabai kering sebagai kontrol, hasil pengeringan yang menggunakan mesin tunnel dehydrator. Karakteristik tersebut meliputi uji kadar air, uji vitamin C dan uji warna menggunakan chromameter.

\section{Pengaruh Penyimpanan Terhadap Mutu Cabai Kering}

\section{Kadar Air}

Kadar air adalah kandungan air yang yang dimiliki suatu bahan dan dinyatakan dalam persen (\%) baik basis basah maupun basis kering. Kadar air cabai merah mengalami peningkatan selama masa penyimpanan. Peningkatan tersebut rata-rata bertambah sebesar 0.0975 $\%$ perharinya. Kurva peningkatan nilai kadar air (basis kering) disajikan pada Gambar 1yang menunjukkan hubungan antara lama penyimpanan dengan hasil analisis 
kadar air pada cabai merah kering. Persamaan linier yang diperoleh adalah $\mathrm{y}=0.0975 \mathrm{x}+8.0732$ dengan nilai $\mathrm{R}^{2}$ $=0.7872$. Nilai kadar air meningkat disebabkan karena penyerapan uap air atau gas dari sekelilingnya. Pada suhu tertentu dengan waktu yang lama terjadi proses perpindahan air, sehingga ketika tekanan uap air bahan tersebut dalam kondisi setimbang dengan lingkungannya, produk sudah tidak akan mengalami penambahan atau pengurangan bobot produk, karena dalam keadaan setimbang. Hal tersebut akan menyebabkan perubahan terhadap produk meliputi perubahan tekstur, flavor, warna, penampakan fisik, nilai gizi, maupun mikrobiologis.

Nilai kadar air berdasarkan perhitungan basis kering sebelum penyimpanan (H-0) diperoleh nilai sebesar 7.43\% (Tabel 1). Semakin tinggi kadar air dalam bahan pangan maka ketahanan bahan pangan terhadap kerusakan semakin rendah. Makanan yang dikeringkan atau dikeringbekukan, mempunyai kestabilan tinggi pada penyimpanan, kandungan airnya sekitar 5-15\% (Winarno, 1992). Pada penyimpana hari ke-24 (H-24) kandungan air yang terdapat pada cabai kering sebesar $10.46 \%(\mathrm{db})$, artinya nilai kadar air pada cabai kering masih tergolong baik karena masih di bawah batas maksimum kadar air dalam bahan pangan kering. Batas maksimum kadar air dalam bahan pangan kering menurut SNI 01-3389-1994 yaitu $15 \%$ atau 11\%. Berdasarkan persamaan linier diperoleh bahwa umur simpan cabai kering berdasarkan kenaikan kadar air yaitu 71 hari.

Tabel 1. Hasil analisis cabai merah keriting varietas TM 999)

\begin{tabular}{lcc}
\hline \multirow{2}{*}{ Parameter } & \multicolumn{2}{c}{ Hasil analisis (kontrol) } \\
\cline { 2 - 3 } & Cabai Segar H0 & Cabai Kering H0 \\
\hline Kadar air (\%) & $79(\mathrm{wb})$ & $7.31(\mathrm{wb})$ \\
Vitamin C (mg/100 g) & 18.62 & 13.47 \\
Warna (chroma) & 18.6 & 17.4 \\
\hline
\end{tabular}

Keterangan : wb $=$ wet basis

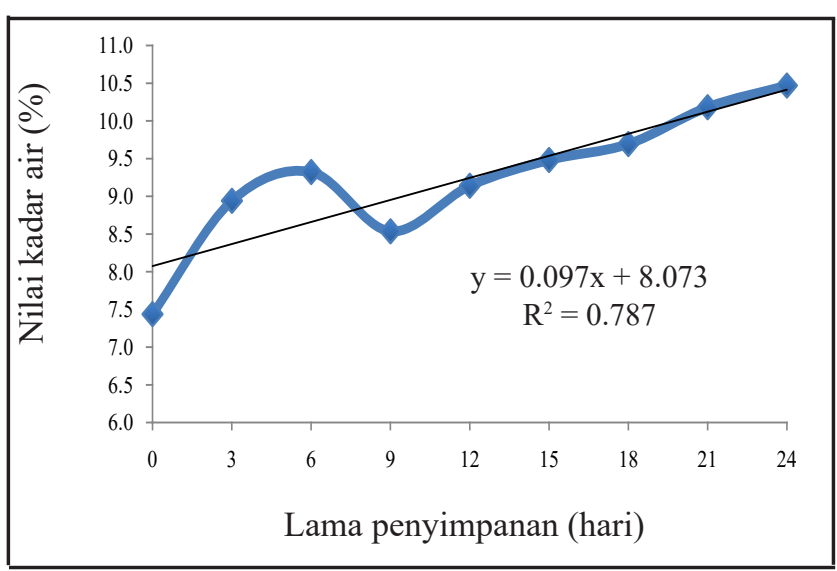

Gambar 1. Kurva hubungan lama penyimpanan terhadap kadar air cabai kering
Vitamin C

Vitamin C merupakan asam organik yang banyak melimpah terdapat dalam sayuran dan buah-buahan, diantaranya yaitu pada cabai merah keriting. Setiap varietas buah cabai memiliki komposisi nilai gizi yang berbedabeda. Selama penyimpanan terjadi penurunan nilai vitamin C. Pada H0 diperoleh vitamin C sebesar $13.46 \mathrm{mg} 100 \mathrm{~g}^{-1}$ dan $7.04 \mathrm{mg} 100 \mathrm{~g}^{-1}$ pada H24. Rata-rata penurunan yang terjadi selama penyimpanan berkisar $0.27 \mathrm{mg}$ per tiga hari sekali. Grafik linier vitamin C terdapat pada Gambar 2. Kurva hubungan lama penyimpanan dengan nilai vitamin $\mathrm{C}$ kemudian dihitung regresi liniernya sehingga menghasilkan persamaan yaitu $\mathrm{y}=-0.27 \mathrm{x}+13.484$ dengan koefisien korelasi (R) sebesar 0.99, dimana y adalah nilai vitamin $\mathrm{C}$ dan $\mathrm{x}$ adalah lama penyimpanan (hari).

Faktor yang menyebabkan kerusakan vitamin $\mathrm{C}$ adalah lama penyimpanan disebabkan teroksidasinya vitamin $\mathrm{C}$ dan adanya perubahan konsentrasi oksigen (Almatsier, 2001). Demikian pula dengan lama penyimpanan akan mempengaruhi nilai vitamin $\mathrm{C}$, semakin lama penyimpanan nilai vitamin $\mathrm{C}$ akan semakin menurun. Penurunan vitamin $\mathrm{C}$ terjadi pula pada proses pencucian saat sortasi serta pemanasan saat blancing dan pengeringan, sehingga ketika disimpan pada waktu tertentu vitamin $\mathrm{C}$ akan terus mengalami penurunan.

\section{Warna}

Warna merupakan indikator utama dalam menentukan tingkat kesegaran pada buah, selain itu warna juga menjadi parameter penting bagi konsumen dalam memilih produk pangan. Pengujian warna diukur dengan mengunakan alat chromameter. Nilai L sebagai indikasi kecerahan (lightnees) dan koordinat cromacity a sebagai indikasi warna merah (+a) serta warna hijau (-a) dan cromacity b sebagai indikasi warna kuning $(+b)$ serta warna biru $(-b)$.

Hasil pengamatan warna selama penyimpanan disajikan pada Gambar 3. Perubahan warna yang terjadi selama penyimpanan menunjukkan bahwa tingkat kecerahan

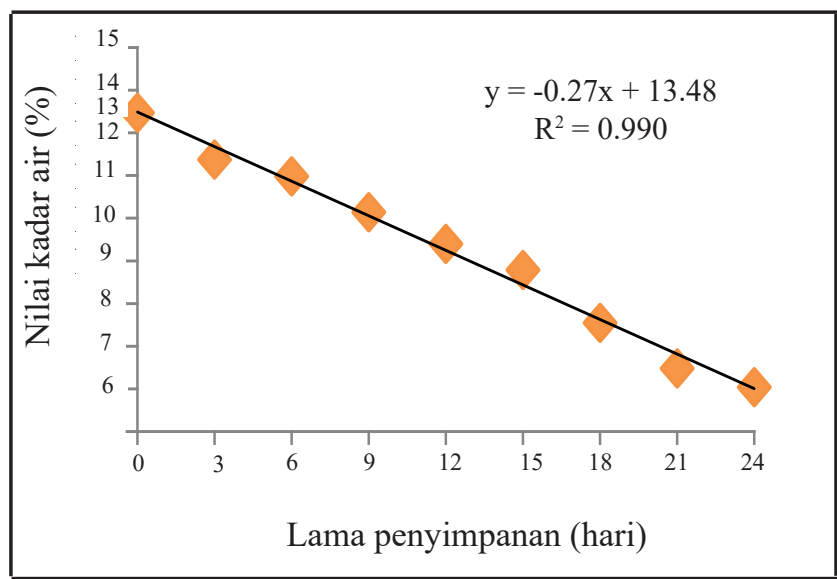

Gambar 2. Kurva hubungan lama penyimpanan terhadap vitamin C cabai kering 
warna (L) belum terjadi penurunan secara signifikan, nilai warna masih cenderung stabil yaitu berkisar 31.6 - 34.5. Warna merah atau $\left(\mathrm{a}^{+}\right)$maupun warna lainnya menunjukkan hasil yang sama, artinya kenampakkan warna cabai kering masih tergolong baik sekali.

Berdasarkan persamaan di atas menunjukkan bahwa tingkat kemerahan $(\mathrm{a}+)$ berkisar antara 9.7 - 14 yang artinya warna cabai kering adalah merah cerah karena mendekati nilai 0, namun tingkat kecerahan (L) cabai kering setiap harinya menurun sebesar 0.368. Penurunan tersebut menunjukkan bahwa semakin lama waktu penyimpanan maka warna cabai kering akan semakin gelap. Tingkat kecerahan (L) erat juga kaitannya dengan tingkat kejenuhan warna yaitu nilai C (chroma). Jika nilai L menurun maka warna cabai kering pun semakin jenuh. Nilai chroma menurun setiap hari sebesar 0.095. Nilai chroma selama penyimpanan yaitu berkisar antara 16-18.3. Nilai tersebut menurut Sanguansri et. al. (1995) merupakan nilai chroma dengan tingkat kelas mutu 2 yaitu tergolong baik sekali.

Perubahan warna yang terjadi disebabkan karena pengaruh panas blansir sebelum penyimpanan dan lama waktu penyimpanan. Kedua faktor tersebut merupakan faktor kerusakan terhadap pigmen karotenoid sehingga warna merah pada cabai berubah menjadi kecoklatan.

\section{Total Mikroba}

Cemaran mikroba sangat berpengaruh terhadap mutu cabai kering, karena dengan semakin banyaknya jumlah mikroba pada cabai kering menunjukan bahwa cabai sudah tidak layak untuk dikonsumsi. Pertumbuhan mikroba sangat dipengaruhi oleh beberapa faktor di antaranya adalah suhu, kelembaban (RH), kadar air, jenis bahan pengemas dan tempat penyimpanan. Cabai yang tercemar oleh mikroba dapat dilihat secara fisik dan dapat diketahui jumlahnya berdasarkan peningkatan nilai TPC (Total Plate Count) atau ALT (Angka Lempeng Total). Secara fisik pertumbuhan mikroba ditunjukan dengan adanya jamur ataupun serangga, menurut SNI 01-3389-1994 (Deptan, 1994) untuk cabai

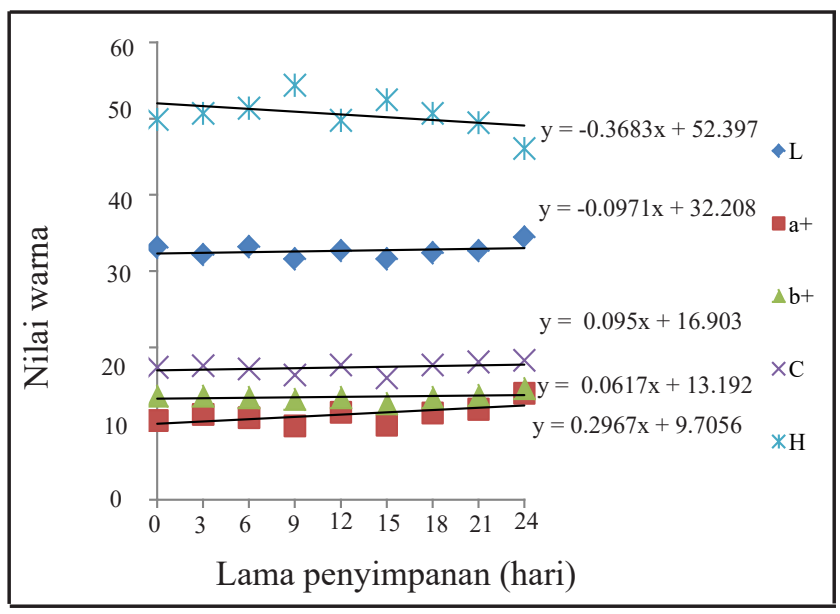

Gambar 3. Kurva hubungan lama penyimpanan terhadap perubahan warna kering mutu I jumlah jamur yang diperbolehkan sebesar $0 \%$ dan maksimal 3\% untuk mutu II. Siagian (2002) mengatakan bahwa bakteri yang dominan mengkontaminasi makanan kering adalah kelompok Clostridium dan Bacillus. Spora kedua bakteri ini dapat bertahan pada proses pengeringan. Penggunaan suhu pengeringan yang tidak bekterisidal, memungkinkan bakteri seperti salmonella dan E. coli tetap ada setelah pengeringan.

Gambar 4 memperlihatkan bahwa pertumbuhan mikroba pada H0 (hari ke-0) didapatkan jumlah mikroba sebesar $4.4 \times 10^{3}$ koloni g $^{-1}$ atau Cfu g-1 dan $1.3 \times 10^{4} \mathrm{Cfu}$ $\mathrm{g}^{-1}$ pada H24. Persamaan regresi hasil analisis TPC sebagai penentu umur simpan cabai kering yaitu $\mathrm{y}=0.0487 \mathrm{x}+$ 8.1831dengan nilai $\mathrm{R}^{2}=0.9301$. Hasil dari persamaan tersebut menunjukkan bahwa pertumbuhan mikroba setiap

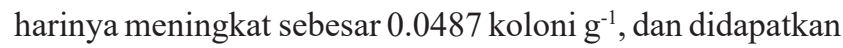
umur simpan cabai kering selama 65.36 hari atau 65 hari mengacu pada syarat jumlah ALT yang ditetapkan oleh BPOM (2009). Batas maksimum pertumbuhan mikroba pada sayuran kering dan pangan olahan lainnya menurut BPOM (2009) adalah $1.0 \times 10^{5}$ koloni $\mathrm{g}^{-1}$ dan $1,0 \times 10^{4}$ koloni $\mathrm{g}^{-1}$.

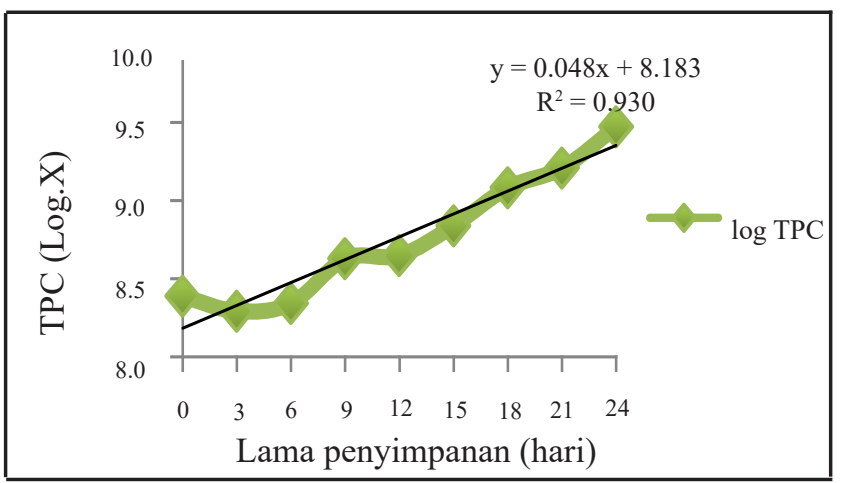

Gambar 4. Kurva hubungan antara lama penyimpanan terhadap jumlah bakteri pada cabai merah kering

\section{KESIMPULAN}

Lama penyimpanan cabai kering berpengaruh terhadap parameter yang diujikan. Semakin bertambahnya waktu penyimpanan, nilai kadar air meningkat begitu pula dengan total mikroba, karena air merupakan media yang baik bagi pertumbuhan mikroba. Semakin bertambahnya lama penyimpanan, kadar vitamin $\mathrm{C}$ dan warna cabai kering mengalami penurunan. Penurunan tersebut ditandai dengan teroksidasinya kandungan vitamin $\mathrm{C}$ dan penurunan kandungan karotenoid pada warna cabai.

Pengeringan cabai merah kering menggunakan tunnel dehydrator dan penyimpanan pada suhu ruang (26-30 $\left.{ }^{\circ} \mathrm{C}\right)$ memiliki umur simpan 71 hari berdasarkan kadar air maksimal dan 65 hari dengan tercapainya jumlah mikroba maksimal, mengacu pada syarat mutu yang ditetapkan oleh BPOM (2009) tentang Penetapan Batas Maksimum Cemaran Mikroba Dan Kimia Dalam Makanan. 


\section{DAFTAR PUSTAKA}

[AOAC] Association of Official Analytical Chemyst. 1995. Official Method of Analysis of The Association of Offial Analytical of Chemist. Arlington: The Association of Official Analytical Chemyst, Inc.

[BSN] Badan Standarisasi Nasional. 2006. Cara Pengujian Bakteri TPC (SNI 01-2332.03-2006). BSN. Jakarta.

Almatsier, S. 2001. Prinsip Dasar Ilmu Gizi. Gramedia Pustaka Utama. Jakarta.

Arpah, M. 2001. Buku dan monograf penentuan kadaluwarsa produk pangan. Sekolah Pascasarjana. Institut Pertanian Bogor. Bogor.

[BPOM] Badan Pengawas Obat dan Makanan. 2009. Penetapan Batas Maksimum Cemaran Mikroba dan Kimia Dalam Makanan. HK.00.06.1.52.4011. Jakarta.

Dahlia, Nyimas. 2002. Mempelajari pengaruh iradiasi terhadap karakteristik edible film dari kacang kedelai (Glycine $\max$ Merr.) varietas Meratus. Skripsi. Fakultas Teknologi Pertanian. Institut Pertanian Bogor. Bogor.
Deasy, W. 2003. Proses produksi dan karakterisasi tepung biji mangga jenis arumanis (Mangifera indica L.) Skripsi. Program Sarjana. Institut Pertanian Bogor. Bogor.

Departemen Pertanian. 1994. Standar Nasional Indonesia (01-3389-1994). Badan Statistik Indonesia (BSN) : Jakarta.

Sanguansri, L., I. Gould, P. Drew. 1995. Improved Quality for Dryed Tomatoes. Final Report No. TM-304, Australian Food Industri Science Centre, Werribee, Victoria.

Siagian, Albiner. 2002. Mikroba Patogen Pada Makanan dan Sumber Pencemarannya. Fakultas Kesehatan Masyarakat. Universitas Sumatera Utara.

Sudarmadji, S., B. Haryono, Suhardi. 1997. Prosedur Analisa Untuk Bahan Makanan dan Pertanian. Angkasa. Bandung. 